\title{
The Tension of the Social Relations between the Colonizer and the Colonized in Forster's a Passage to India
}

\author{
Abdulhafeth Ali Khrisat \\ Department of English, Faculty of Sciences and Arts/Khulais \\ King Abdulaziz University, Jeddah, Saudi Arabia \\ E-mail:drkhrisat@gmail.com
}

\section{Doi:10.5901/mjss.2013.v4n10p27}

\begin{abstract}
Colonialism is a practice of dominion which involves the subjugation of one people to another. The British colonized India and left an impact on many different levels of life and culture. E. M. Forster's A Passage to India, referring to colonialism, explores the relationship between the colonized, an Indian doctor, and the colonizer, a British schoolmaster. This paper aims to explore Albert Memmi's concepts of colonialism as presented in his The Colonizer and the Colonized (1974) and examine Forster's characters according to these views. One basic issue is the cultural misunderstanding between the colonizer and the colonized. Different types of characters in the novel embody a number of Memmi's ideas. The colonizer is characterized by profit, privilege and usurpation. Lack of communication comes at the core of the relationships seen in the social context between the English and the Indian, since colonial India suffers from mistrust and racial hatred.
\end{abstract}

Keywords: Forster, colonialism, India, A Passage to India, culture, tension.

\section{Colonialism and India}

Colonialism in India is often misconceived as the victory of the military rule. Actually, the British colonialism in India owes its success to the soft expressions of control. Colonialism is, thus, the project of control upon the minds of the people who are colonized (Gupta: 2006). Colonial knowledge has enabled the colonizers to rule and divide the occupied society into parts. Cultural forms in societies are newly classified as "traditional" and are reconstructed and transformed by that kind of knowledge. It has created new categories and oppositions between the colonizers and the colonized, European and Asian, modern and traditional, and West and East (Orwell, 1946). According to Dirks (2006), colonial conquest is not only the result of the power of superior arms, military organization and political power, but also of the economic wealth. Dirks says that "Colonialism is made possible because it is sustained and strengthened by cultural technologies of rule that is established on foreign shores by the British ruler" (7).

Said (1994) reveals a message that imperialism is not about a moment in history; it is about a continuing interdependent discourse between subject peoples and the dominant discourse of the empire. Despite the apparent and highly-praised end of colonialism, the unstated assumptions on which empire was based linger on, eliminating visions of an "Other" world without domination and restricting the imaginary of equality and justice (35).

Albert Memmi presents views on colonialism in his The Colonizer and the Colonized (1974). These views are embodied in different types of characters in Forster's A Passage to India (1924). One basic issue that dominates the narrative is cultural misunderstanding between the colonizer and the colonized. This theme of colonialism is further discussed through the British colonial occupation of India. Human relationship is explored in the friendship between an Indian doctor and a British schoolmaster during a trial against the doctor based on a false charge.

\section{Forster and Colonialism}

Lilburn (1998) states that although Forster has stated that the novel is not really about politics and that it is less concerned with the incompatibility of East and West than it is with the difficulty of living in the universe, yet, the novel attacks the traditional justifications for British domination and existence in India. So, these justifications have helped in creating the tension in the social relationship, especially the friendship between the Indians and the British. Yousafzai and Khan (2011: 76) believe that Forster's thesis is that "violation of the human values is the root cause of tension." 
Abu Baker (2006) agrees that colonization is frustrating to develop friendship between the English and the Indians under the colonizer and the colonized status-quo. He comments on Forster's A Passage to India, believing that Forster highlights the process of "formatting", which the newcomers have to go through so that they end up like the other colonial settlers in terms of their ideologies and practices (68-9). A Passage to India (2002) features British characters who have internalized the ideological assumptions of their natural superiority over the Indians, yet many, when actually carrying out their imperialistic duties distant from the mother culture, often find their assumptions strained not only because of the stress of the tropics but also because these assumptions are not inherently true but are components of a version of reality that justify the British Empire's existence. A Passage to India is part of the realistic tradition in literature; it is typical in its realistic representations of the historical conditions in their respective periods and is similarly typical in its treatment of the "culture clashes" between Europeans and the natives they encounter.

\section{Colonialism: Tension between the Colonizer and the Colonized}

The colonial situation is clearly depicted by Forster in A Passage to India; India is a colonized society where the colonizers who see themselves as superior and the colonized who are seen as inferior live side by side and deal with each other directly. This is revealed in the complexity of the interaction between both sides; Adela does not even think to deal with the Indian women or to be like them. There is also misunderstanding between these two groups because of the different cultures; this tension becomes obvious in the social interaction between the two groups when Aziz invites Mrs. Moore, Adela and other English women to visit the Marabar Caves; he worries a lot about cultural differences and greatly fears offending the women through cultural insensitivity; he wishes to adapt the trip to English values to the greatest extent possible. This shows the difficulty of social interaction between the English and the Indians. Even when both groups have the best intentions, the differences and the tension between them make it difficult to the groups to interact casually. This can be seen through the mistake which causes Fielding and Godbole to miss the train.

However, Aziz's attempt to establish friendships with several British characters has disastrous consequences. In the course of the novel, Aziz is accused of attempting to rape a young English woman, Miss Quested. Aziz's friend, Fielding, helps to defend him. Although the charges against Aziz are dropped during his trial, the gulf between the British and native Indians grows wider than ever, and the novel ends on an ambiguous note.

According to Turkmen (2003), the identity issue is mostly handled within the sphere of the colonized. However, the colonial identity goes beyond the colonized. It is between the colonizer and the colonized. The issue is aligned with the colonized as the colonized in the colonial system is the victim, yet, when one makes an analytical reading, one will bear witness that the colonizer is victim too, in that he also faces the same problem: fading identity. The colonizer's identity comes into conflict with the colonized's one. A Passage to India opens with a discussion between some characters about the possibility of having a friendship between the colonizer and the colonized. The novel begins emphatically with Dr Aziz, Mahmoud Ali and Hamidullah discussing whether or not it is possible to be friends with an Englishman. The three characters agree that it is impossible for this to happen in India. The novel ends with Fielding and Aziz leaving each other because such a friendship is not possible under British occupation. It unwinds itself and reaches point zero once more. The English and the Indians can become more intimate, but the problems of cultural differences, stereotyping, and colonization prevent the possibility of having a real friendship between them. It is entirely difficult to establish a friendship or any good relationship between two groups with different cultures, religions and traditions, and above all, none of them try to understand the other.

Birodkar (2007) states that Britain and the colonies have tensions between each other from the time that the adventurous colonists want to branch out away from the powerful grip of Britain. Although the British do not want to let the colonists run their own country, they still believe that an extension to their country would be very beneficial to their economy and power. However, colonialism changes the social structure and makes the colonized lose his cultural identity. Such price is paid by the main character in the novel, Aziz, who suffers a lot because of his trust to the English woman, Miss Quested; she accuses him for trying to rape her. Also, he pays for his friendship with Fielding who consequently stands with Miss Quested and believes that Aziz tries to rape her. Under these circumstances, the good relationship that links Aziz with Fielding has been destroyed. This is clear evidence that such friendship between the colonizer and the colonized can never be maintained if it really occurs.

\section{Memmi's Views on Colonialism}

Memmi's The Colonizer and the Colonized (1974) is specifically in response to the decolonization of North Africa in 1956, 
when his home nation Tunisia, as well as its neighbor Algeria, gained independence from the French. Memmi describes this work as "portraits of the two protagonists of the colonial drama and the relationship that binds them." (145). The British and the native peoples are both encouraged to view the imperialistic relationship as good for everyone. Yet, at the same time, a system of cultural assumptions is put forth based on emphasizing and exaggerating the differences between the colonized and colonizer and citing these differences as evidence that the colonizer is "naturally suited to govern as the colonized is to be governed" (71).

The Colonizer and the Colonized proves to be highly influential, as well as highly controversial work, "citing colonization as a variant of fascism" (63). Memmi states that the dynamics of colonization are similar in any colonial system. In his view, under colonial governments, "once the colonizers gain political and economic power, they become the exploiters" (37). Memmi's primary argument is that the collapse of colonialism is inevitable and that the only means for this eventual collapse will come through revolt. Memmi defines the colonizer as "a person who imposes his culture a way of life that includes government, education and socioeconomic system on another in total disregard of the latter's culture" (25). In the process of colonization, the colonizer becomes an illegitimately privileged usurper.

Memmi believes that there are three factors that specify the colonizer (any European in a colony): profit, privilege, and usurpation. Europeans living in colonies often consider themselves to be in exile. They are not inclined to leave the colony for their mother country because they are able to live a more comfortable life in the colony. For the colonizer, "a colony is a place where one earns more and spends less" (5). Throughout A Passage to India, the barriers to inter-racial friendship in a colonial context are explored, and personally experienced by Fielding and Aziz. Forster reveals this point in the novel; when Aziz and other characters were discussing Indian education. Aziz asks if it is fair that an Englishman holds a teaching position when qualified Indians are available. Fielding cannot present the proper answer for this conversation which is that England holds India for her own good. Fielding, instead, says that he is delighted to be in India. So, for him, and other Britaish, India is a comfortable place to enjoy. The main motive in colonization for England is wealth that is gained through the exploitation of the natives; the British justify their actions to the world and to themselves and question one's cultural and personal identity.

Memmi believes that the colonial system is fundamentally unstable and will lead to its own destruction due to the mere rigidity of the system: "the colonized have ultimately two answers to the colonial system" (126). The first is assimilation, which is to change his condition by changing his skin, and this is impossible since it is never desired by the colonizer, and all those colonized who have attempted it are deluded. The other option is revolt, which, according to Memmi, is as inevitable as the failure of assimilation. Being unable to change his condition in harmony and communion with the colonizer, the colonized tries to become free (127). Subsequently, the only tool left to the colonized is to reclaim their liberty by force, so revolt is the only effective solution that Memmi puts emphasis on.

Having established that the relationship between the colonizer and colonized is unstable by virtue of its consequences, Memmi then seeks to show why colonialism can only end through revolt. This issue is shown clearly in the novel which begins and ends with a question: can the English and the Indian races be friends? At the end of the novel, the answer appears to be no; "No, not yet" (289). This is clear evidence showing that the only redeem for colonization is through revolting and getting the colonizers out. In the last scene of the novel, the people of Chandrapore make riots after Aziz's arrest asking the colonizers to leave India. That gives Mrs. Moore a good reason to return to Britain.

\section{Conflict between the Colonized and the Colonizer}

A Passage to India, in general, talks about the British colonization of India in the city of Chandrapore at the time of the Raj. In the first part of the novel, Mrs. Moore and her Adela are newly arrived in Chandrapore where Mrs. Moore's son, Ronny has the post of City Magistrate. Forster decides that the Indians and the English are incompatible. They can pretend and desire to be friends, but they cannot be friends. Even Fielding, who tries to befriend the Indians, is aware of the profundity of the gulf that divided him from them. Matters develop further when Fielding invites the two ladies, Mrs. Moore and Adela, to meet Aziz and Professor Godbole, one of his Brahman colleagues, at a tea party. Unfortunately this, too, is a failure when Ronny's arrival sours the atmosphere and the party breaks up in some disorder. Adela has decided that India has changed Ronny and she no longer wishes to marry him. Meanwhile, Aziz and Fielding have taken to each other and have become close friends.

The second part of the novel revolves around the mysterious Marabar Caves. Aziz has impulsively invited the English ladies to visit these local curiosities at Fielding's tea party and feels compelled to go through with his scheme although no one is very enthusiastic. From the start, the expedition is dogged with misfortune; Fielding and Godbole are 
late and miss the train; Aziz and Adela continue to a high rock with a single guide, but become separated and enter different caves. Aziz emerges to find that Adela has gone down the hill and returned to Chandrapore in a passing car. Fielding arrives late and the party returns home to discover that Aziz has been charged with attempted rape. Attitudes in the community polarize and harden. Fielding, who is confident of Aziz's innocence, resigns from the English club and throws in his lot with the Indians. Mrs. Moore is similarly certain that Aziz is not guilty but, ill and disillusioned; she decides to go home to England early and dies at sea. Aziz gets frustrated after many situations of misunderstanding and doubts between the two groups.

Finally, the matter is brought to a trial where Adela is shunned by the Anglo-Indian community. The two characters who have tried to establish a good relationship between each other, Fielding and Aziz, both suffer. This part of the novel ends with Adela and Fielding returning separately to England. The narrator concludes, two years later, in the native state of Mau, Fielding, back again to India and being promoted, has arrived in an official capacity to inspect the new school.

One can notice that Forster's portrayal of the characters Ronny, Adela, and Fielding shows the three different types of colonizers that Memmi observes in his own life as a suppressed native, in addition to Forster's portrayal of Aziz who typifies the colonized. Each character portrays a different situation and mind set, demonstrating the different alternatives in the colonial and imperial life. Through these characters, one truly sees the effects that imperialism has not only on the colonized, but also the colonizer. This mind set is seen clearly through analyzing these four characters.

Ronny, Mrs. Moore's son, represents the colonizer, pride, prejudice, arrogance and harsh treatment. He typifies the sun-dried bureaucrat and Anglo-Indian. He is condescending and cruel toward the Indians, believing that he is in India not to be kind, but rather to rule over the nation. He becomes a martyr during the trial because of the ill treatment of Adela, but he shows himself to be manipulative and hard when he pushes to have his mother leave India when he fears she may hurt the prosecution case. So Ronny is, according to Memi's description, "The colonizer who accepts" (89); he actually enjoys being a colonizer and benefits from being a member of the ruling class. Memmi argues that the colonizer, who is content with this role, has to maintain continually the pretense that the colonized are inferior and subhuman in every respect; otherwise, guilt becomes overwhelming as for "the colonizer who refuses" (63) to participate directly in colonial subjugation. Even if this person joins in the freedom movement, he will still have to give up much of his own identity and cannot be guaranteed a place in the independent nation.

Fielding, who is the schoolmaster of Government College, stands alone among the British officials in India, for he is one of the few to treat the Indians with a sense of decency and respect. Fielding is an individualist who has no great allegiance to any particular group, but rather to his core set of liberal values and sense of justice. This quality allows Fielding to break with the English who support Adela's charges against Aziz and side with the Indians in support of him. Fielding is described in the novel as, "essentially a cultured humanist, an educator, agnostic and a warm-hearted man....He is an intelligent man in his forties, with a strong belief in the efficacy of education and culture" (Forster: 14). However, the events surrounding Aziz's trial cause Fielding to become disenchanted with India despite his affection for the nation and motivate him to leave India and return to resume a different post. In India, he finds himself divided from local British officialdom primarily because of his liberal creed. The local Anglo-Indians dislike and distrust him because he is a disruptive force in their official ranks. He disbelieves in their herd-instinct, because his mind has been nourished on values of personal relations and individual integrity: "Forster seems to have lost his faith in human relations as sole remedy against human ills" (Ziaul Haque: 2012).

Therefore, Fielding is not much appreciated by Anglo-India, especially by its women, because he is not an AngloIndian sahib, and he is not interested in them at all. He begins to like the company of Indians. In this aspect, Fielding seems to represent Forster; he is excessively kind in his behavior towards his Indian friends, but is sometimes puzzled whether it requires "an occasional intoxication of the blood" (Forster: 111). He is friendly, but not quite intimate with Aziz, or with anyone. Aziz admits that saying to the Principal when he visits him, "No Englishman understands us except Mr. Fielding" (87). Fielding, as being Memmi's "the colonizer who refuses" does as Memmi has suggested that such person refuses his rule as a colonizer, he then must leave the colony. Fielding is immediately denounced as he rejects this role of imperial aristocrat for benevolent humanitarian. Memmi states that such type of character cannot completely join the colonized because above all he is still British and, therefore, holds the same ideas and prejudices that he has grown up with. He, in the end, turns back to his own people, marrying an English girl.

According to Newman (2005), it is significant that Fielding returns to England to find his girl and that he becomes more of a part of the imperial society with his marriage ties, but he remains free of the change that occurs in the colonies by making his match away from India: "He stays free of the role of imperial actor and continues on with his notions of friendship and peace with the Indian people" (Forster: 4). So, Forster presents Fielding as an example of how to resist 
the imperial Indian machine and yet still maintain his British culture. Some of the characteristics of Fielding may be too shown in Adela who arrives in India with the intention of marrying Ronny, but changes her mind several times and eventually realizes that she does not love him and cannot marry him. She is a woman of conflicting character traits; although an intellectual, she is short-sighted. Although she foolishly accuses Aziz of assaulting her in the Marabar Caves, she finds the courage to withdraw the charge. However, Forster finally reveals her to be a woman of character and who accepts the difficulties she suffers.

\section{Colonialism and Cultural Misunderstanding}

Through characters' interactions and dialogues, Forster emphasizes that one of the major effects of colonization is cultural misunderstanding. Different cultural ideas and expectations regarding hospitality, social proprieties and the role of religion in daily life are responsible for the misunderstanding between the English and the Muslim Indians, the English and the Hindu Indians, and between the Muslims and the Hindus. Aziz tells Fielding at the end of the novel: "It is useless discussing Hindus with me. Living with them teaches me no more. When I think I annoy them, I do not. When I think I don't annoy them, I do" (Forster: 288). The British could not understand properly Indian's own traditions of religion and culture, for instance, Godbole's conversation with Fielding about the Hindu view of God sounds strange to him when he tells them that he does not believe in God; in other words, he does not have the concept of belief or disbelief.

Forster demonstrates how these repeated misunderstandings become hardened into cultural stereotypes and are often used to justify the uselessness of attempts to bridge cultural gulfs. When Aziz offers his collar stud to Fielding in a demonstrative act of friendship, Ronny later misinterprets Aziz's missing stud as an oversight and extends it as a general example. Fielding, the colonizer, is tempted to accept his part, whereas Aziz, the colonized, is forced to accept being colonized based upon Memmi's view.

Another example of misinterpretation on the part of the English is when Ronny comments on the missing collar stud and how it indicates the Indians' inattention to detail. In fact, it isn't Aziz's thoughtless dressing habits but his thoughtfulness in loaning Fielding his own stud; this is another breakdown in communication, since Aziz has lied and said he has had a spare. This irony shows the English's lack of the ability to communicate properly with the Indians.

The idea of people reaching out for meaningful connection, but being frustrated, is much in evidence through the story and seems to be an essential part of its pattern. Adela considers marriage and wants to see the real India, but her attempts to complete both projects end in disaster; the failure of the Bridge Party and Fielding's tea party lead to catastrophe in the ominous Marabar caves, which in turn leads to her eventual social ostracism and the break-up of her engagement. Her failure to find love with Ronny is duplicated by Aziz and Fielding in their unsuccessful attempt to cross the racial division and make a lasting friendship. Both of these relationships are seen in social context that is hopelessly divisive, for colonial India is full of mistrust and racial hatred. Only the relationship between Aziz and Mrs. Moore gives any grounds for optimism and this seems strange, rather unlikely bond between two people divided by age and race, and because the British did not use to understand the Indian and they try to separate themselves from the Indians. Mrs. Moore comes to be different from all of the British and even different from Adela who comes to see the real India; it is because Mrs. Moore comes to see the Indians, not only India, but also its people. Probably, this could be the reason why her relationship with Aziz maintains properly. Mrs. Moore, too, being shocked after few days of her arrival to India, returns home full of despair and so dies at the road to England. And finally, Fielding loses his strong friendship because of the misunderstanding between him and Aziz. All these problems shown in the novel are created because of colonization.

Another example about miscommunication which is clear in the novel is the Bridge Party, representative of IndianEnglish relations, which is organized by Mr. Turton; it is an attempt at bridging the communication gap between India and England. First, for the most part, there is a lack of communication altogether between the Indian guests and the English guests. The attempts made are forced and stiff. The British behave generally poorly towards the Indians. There is obviously a tension and a failure of communication between the colonial power and the subject races here that produce both comedy and pathos. Mrs. Turton has no intention of communicating with her perceived inferior while the two English visitors find their own attempts frustrated by the constraints of the occasion.

The Bridge Party is an ironic comment on the attempt to make East meet West and explore the areas of friendship. It is comic reversal of the spirit of the meeting of Aziz and Mrs. Moore in the mosque. Forster exposes the haughtiness and arrogance of the English ladies, especially Mrs. Turton. The Bridge Party does not go beyond formal civilities and surface graces in spite of sincere efforts made by Mr. Turton, Mrs. Moore, Adela and Fielding. The Indians 
are no less responsible than the Anglo-Indians for this dismal failure because they are too self-conscious to share freely in the pleasure of the conversation.

Ronny speaks of the traditional justifications for colonization saying to his mother: "We're not out here for the purpose of behaving pleasantly. We're not pleasant in India, and we don't intend to be pleasant. We've something more important to do" (Forster: 51). Ronny here shows a real evidence for the suffering that the colonizers face in the colonized land. Such evidence is also shown in the character, Adela, who comes for the purpose of marrying Ronny, but returns to England depressed and alone after discovering that India has changed Ronny. Ronny hates Aziz and always depresses him all the time because he believes that Aziz, though educated, still very inferior to him, and that he, as a colonizer, should rule the dark and the inferior races.

It is easy to notice the arrogance of the English in Chandrapore. They have convinced themselves that their presence is necessary for India because they believe that Indians are unable to lead themselves. In the English club, a kind of group-think prevails. The English always think the Indians are devious and act from some ulterior, usually unworthy, motive. For example, when Mrs. Moore tells Ronny that Aziz, whom she meets in the mosque, has spoken ill of Major Callendar, Ronny says that Aziz must have done this to impress her: "It's the educated native's latest dodge. They used to cringe, but the younger generation believes in a show of manly independence" (Forster: 36). Ronny tells his mother when she asks him: "Do kindly tell us who these ladies are ... You're superior to them, anyway. Don't forget that..." (43) Again, this dealing of superiority characterizes the colonizer.

Memmi argues that the colonized society is a diseased society in which internal dynamics no longer succeed in creating new structure. Such society cannot dissolve the conflicts of generations, for it is unable to be transformed (143). These conflicts are resulted from the cultural and social differences which cause tension between the Indian and the British characters in Forster's novel. In A Passage to India, it is necessary to show the relationships and bonds that are created or affected during the British presence and occupation of India and indicate that the effect of the British on India is mainly negative and it isn't a good thing at all for Indians. Despite the fact that Adela and Aziz actually are good to each other, yet, Adela falsely accuses him of trying to rape her. Moreover, the effect of this bond is rather great on the Indian side. Though that Forster is conveying the message that it is really hard to create this relation and even if it is done, it is impossible to keep forever. In addition, there is the bond between Aziz and Mrs. Moore. An example would be how Aziz and Fielding made a really good friendship at the beginning and how they have a certain bond between each other, but when Fielding takes Adela into the college, this bond has broken. The British do not accept the Indian culture nor even think of glorifying it; they just want to create a new British culture in India; therefore, it has created a tension between them and the Indians do not accept the idea of the imposed British culture. The difference in cultures of the colonizer and the colonized has put them in many clashes and conflicts as shown in the novel.

In A Passage to India, there is a fundamental importance of the existence of races with their social and cultural differences. This notion is in the separation between the English, or Anglo-English, and the Indians. This is the most explicit in the narrative of the club where the exclusion of Indians seems to create a private oasis for the English and so enables Adela to exclaim: "I want to see the real India" (Forster: 28). She continues by stating: "I've scarcely spoken to an Indian landing" (30), and so affirms the separation of the race. This separation is built upon physical and social differences where the race of the Indians is separated from the British due to their darker skin and black hair and due to their different traditions. This frames the encounter between Mrs. Moore and Aziz, as the point of difference: "she was older than Hamidullah Begum, with a red face and white hair" (25).

Aziz feels that "The English are a comic institution" (Forster: 65) and he likes being misunderstood by them because he does not want to be part of this comic institution, and because he utterly believes that his mentality cannot meet with any one's of the colonizer and that the natural thing is not to have understanding between these two unbalanced groups. So he sees that it is fair to be misunderstood by them, since they never try to understand the colonized. Forster ends A Passage to India with a bittersweet reconciliation between Aziz and Fielding but also with the two cannot be friends under contemporary conditions. Aziz, thus, completes a movement from kindness and generosity of spirit to bitter and cynicism and back. Fielding, in contrast, realizes that he is in fact a true Englishman and belongs among his own race to defy his race; maintaining an active friendship with Aziz would be just but not pragmatic. This brings back the theme of responsibilities and limitations of racial identity. In this manner, Forster ends $A$ Passage to India as a tragic but platonic love story between the two friends who are separated by different cultures and political climates.

Aziz and Fielding, on their last ride, begin to wrangle over Indo-English politics; Fielding is no longer apologetic about the British Empire in India, whereas Aziz declares that the British in India are of no use. Aziz tells Fielding that the British should clear out of India as quickly as possible. Fielding jeeringly asks whether Indians would then welcome the 
Japanese, and Aziz mockingly answers, "No. Afghans, my own ancestors" (Forster: 297). Later Aziz cries, "India shall be a nation! No foreigners of any sort! Hindu and Muslim and Sikh and all shall be one!" (297). Fielding mocks these nationalists claims but Aziz continues to say "Down with the English!" (297). He says that at least his sons will drive the British out of India! And once this is accomplished, "You and I shall be friends" (298). Fielding who is still dominated with the charm of personal relations, wishes their relationship to develop: "It's what I want. It's what you want" (298). But neither the horses, nor the earth, nor the sprawling countryside of Mau want it. They declare in their manifold voices, "No, not yet" and the sky says, "No, not there" (298).

\section{Conclusion}

To conclude, one can clearly realize the reasons for the tension of the social relations between the colonizer and the colonized; different religions, languages, cultures, traditions, different ways of life and above all, none of both sides try to understand the other; the colonizer deals so cruelly with the colonized, and the colonized hates the colonizer as a reaction. Forster's A Passage to India is a very keen and demonstrative work that shows these different and repeated misunderstandings between these two opposite parties. There are many situations that really describe this tension between the colonizer and the colonized and the difficulty in dealing properly with each other.

\section{References}

Abu Baker, A. (2006). "Rethinking identity: the colonizer in e. m. forster's A passage to india." Nebulas 3 (2-3): 68-85.

Birodkar, S. (2007). "The british come to rule india and the return of indian sovereignty, hindu history." Retrieved May 4, 2008, from http://www.hinubooks.org/sudheer_birodkar/hindu_history/landbritish.html

Dirks, N. (2001). Castes of mind: colonialism and the making of modern India. New York: Princeton University Press

Forster, E. M. (2002). A passage to india. London: York Press.

Gupta, A. (2006). British form of colonialism in india, insanity revamped. Retrieved, November 16, 2007, from http://insanearpit.blogspot.com/2006/09/british-form-of-colonialism-in-india.html.

Lilburn, J. (1998). "A passage to india, criticism. essay for novels for students," Retrieved July 20, 2008, from http://www.answers.com/ topic/a-passage-to-india-novel-7.

Memmi, A. (1974). The colonizer and the colonized. London: Souvernir Press.

Newman, J. (2005). "The effect of colonialism on the colonizer in a passage to india." Associated Content, 19: 7-9.

Orwell, G. (1946). A collection of essays. San Diego: Harcourt Brace Jovanoich.

Said, E. (1994). Culture and imperialism. New York: Random House.

Turkmen, S. (2003). "Identity in the colonial land: a critical overview of psychological studies." Alternatives 2 (1\&3): 195-196.

Yousafzai, G. and Khan, Q. (2011) "Rudeness, race, racialism in E.M. Forster's a passage to india." Dialogue 4, (1): 75-92.

Ziaul Haque, M. (2012) "Colonialism in e. m. forster's a passage to india." www.articlesbase.com/fiction-articles/colonialism-in-e-mforsters-a passage-to-india. 